\title{
Comparing Responses of Local Honeybees (Apis mellifera L.) to Karl Jenter and Doolittle Grafting Queen Rearing Methods
}

\author{
Kibebew Wakjira, Taye Negera, Shimu Dabela, Tadele Alemu \\ Oromia Agricultural Research Institute Holeta Bee Research Center, Holeta, Ethiopia
}

Email address:

wkibebew@gmail.com (K. Wakjira)

To cite this article:

Kibebew Wakjira, Taye Negera, Shimu Dabela, Tadele Alemu. Comparing Responses of Local Honeybees (Apis mellifera L.) to Karl Jenter and Doolittle Grafting Queen Rearing Methods. International Journal of Animal Science and Technology. Vol. 3, No. 3, 2019 , pp. 35-40. doi: $10.11648 /$ j.ijast.20190303.11

Received: June 22, 2019; Accepted: August 6, 2019; Published: August 23, 2019

\begin{abstract}
A study was conducted in view of analyzing the responses of central highland honeybees (Apis mellifera bandasii) to Karl Jenter and Doolittle grafting queen-rearing methods at Holeta for two consecutive active seasons. The result of the study revealed that there was significant difference $(\mathrm{p}<0.001)$ between the techniques in percentage of accepted larvae and sealed queen cells. The acceptance rates for Karl Jenter and Doolittle grafting queen rearing methods were 78.19 and $50.81 \%$, respectively while the rates were 42.75 and $25.56 \%$ for sealing, respectively. However, the result of the study showed that the rate of hatching (out of the total given larvae) into virgin queen stage in Karl Jenter and Doolittle grafting systems were about 23 and $23.8 \%$, indicating no significant difference between the two techniques. From this study it is recommended that using Karl Jenter kit is an excellent option to overcome the problem of indentifying appropriate larvae for grafting under field conditions. However, there might be a difference in quality of the queens obtained from these two methods. Therefore, also further study recommended to evaluate the performance of queens reared using the two techniques.
\end{abstract}

Keywords: Apis mellifera bandasii, Jenter, Honeybees, Cell Cup, Queen Rearing

\section{Introduction}

A honeybee queen alone has significant effect on the colony and is one of the most important factors in a bee colony's production and productivity performances [1]. Several production and productivity traits such as disease resistance, prolificacy, and early population build up, surplus honey storing tendency and many other behavioral characters are attributed to the nature of a queen [2-4]. Therefore, in order to improve performances of a honeybee colony, better performing queen is one of the indispensable parts of beekeeping. In this regards, artificial queen rearing techniques, is one of the important approaches to help producing of queens with desirable characters in beekeeping to regularly re-queen colonies, to minimize swarming tendency, to enhance brood and honey production, and increase colony stock number. Other desirable traits of a colony like calmness and disease resistance are governed by the genetic makeup of the queen, which generally indicates the importance of queen rearing [5-7]. Towards this, researchers have tried to produce queens from appropriate larval stages by involving different queen rearing [2, 4, 8-11] however, no convenient and economical method has been developed as recipe to fit all races of bees, and all beekeepers and conditions $[8,9]$.

Some studies on responses of local honeybees to queen rearing techniques $[12,13]$ indicated that different queen rearing methods can be employed to produce queens. However, the responses of colonies towards different queen rearing techniques were greatly varying from technique to technique and seasons to seasons. Similarly, variation of responses to different queen rearing techniques by honeybees were well documented elsewhere $[2,6,7,9]$. On top of the variation in responses to the techniques, environmental conditions like temperature, relative humidity and pollen source plants were also indicated as important determining factors in level of acceptance and quality of reared queens artificially [6,7]. Moreover, variations in diameter of 
artificial queen cell cups also affects acceptance rate of grafted larvae [7, 8]. Generally, different techniques affect responses and rates of acceptance and quality of the reared queens. Besides the types of techniques used, the number of young worker bees, the status of brood and food resources were reported to influence the response and quality of the reared queens $[4,6]$. Consequently, the aim of the present work was to investigate the responses of local honeybees (Apis mellifera L.) to Jenter queen rearing method and compare larval acceptance, sealed and emerged queens with Doolittle grafting queen rearing technique under central highland part of Ethiopia.

\section{Materials and Methods}

\subsection{Study Site, Experimental Colonies and Treatments}

The study was conducted in Central Highland areas of Oromia National Regional State, Ethiopia specifically at Holeta apiary site from September 2016 to May 2018 for two years during breeding seasons, September-October and April-May. Apis mellifera bandasii colonies within the movable Langstroth type frame hives were used for the study. Detailed descriptions of the biological characteristics and variations of the race is given elsewhere [14]. All the colonies were fed with one-liter sugar syrup (2:1 sugar and water) twice for the colonies to attain the required strength at the onset of each breeding season during the study.

To assess the responses of colonies to Jenter queen rearing system and to compare their responses with that of grafting system, a total of 24 colonies in hives of 10 frame with single super were used. The test was done by involving four different batches of colonies throughout the study. For both treatments, each colony received 24 to 36 hours old larvae and data on number of accepted larvae, sealed queen cells (pupae) and queen hatched were collected to see the responses of colonies to Jenter queen rearing method and the result compared with the data for grafting.

\subsection{Experimental Setup}

Standard plastic Karl Jenter method (Model Karl-Heinz Jenter Company Steinbeisstraße 5, 72636 Frickenhausen, Germany) and Doolittle grafting method with plastic cell cups were used to analyze the responses of local honeybees to the methods and to available information for the potential users under local conditions.

For Karl Jenter method, a total of 12 well fed local honeybee colonies (two breeders, five queenless starters and five queenless builders) with uniform strength in Langstroth hive with the population size of first super were used. The Karl Jenter queen kit system was inserted into the two breeder colonies to get young larvae that subsequently transferred to the five queenless cell starter colonies. For the production of young larvae, section of brood combs obtained from breeder colonies were cutout equal to the size of the Karl Jenter kits and each kit fitted into the cutout section two days prior to confinement of the queen for egg laying so that the bees can polish and clean up the kits. Then after two days, two preselected selected breeder queens confined into the kit to let them fully lay eggs on tops of removable cell plugs (Figure 1). After 24 hours, the queens released and the kits maintained in the same colonies for further 72 hours $(3$ days) for allowing the eggs to hatch into 24-36 hours old larvae. The starter colonies were made queenless one day in advance before transferring the cell plugs of hatched larvae. 24 hours after the five colonies made queenless, the Karl Jenter queen rearing kit with hatched larvae were transported to laboratory, a total 200 starter cups extracted along with cell plugs from the back of Karl Jenter Jenter kits, inserted into standard queen cell cup holders and attached on 10 wooden cell bars. Then 2 cell bars with the attached cell cups were fixed into a standard frame on the same day and each placed in the five colonies made queenless one day in advance for acceptance of the larvae and starting queen cells. 24 hours after placed in starter colonies for acceptance, inspection of the colonies was done and number of accepted larvae for each starter colonies recorded. On the same day, cell builder colonies were made queenless to receive the accepted larvae by the starter colonies. After 24 hours further in starter colonies, accepted cell cups were transferred to the builder colonies. Then, after a week in cell builder colonies, the number of matured queen cells (pupae) recorded and each matured queen cell placed in queen cage for hatching in the same colonies. For each test colony, 40 cell plugs on standard queen cell cup were used and the testing was repeated two times each active season and accordingly eight batches of queen rearing conducted during the whole study period.
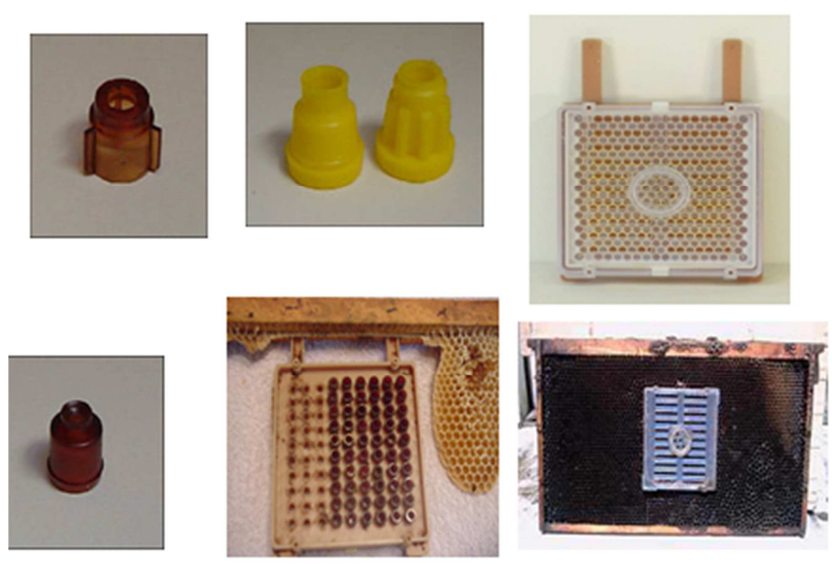

Figure 1. Jenter queen rearing kit, showing inserted cell plugs into the confined queen lay area of frame.

For Doolittle grafting method, a total of 12 well fed local honeybee colonies (two breeders=larval suppliers, five queenless starters and five queenless builders) with uniform strength in Langstroth hive with the population size of first super were used. In this case, combs with larvae of age 24-36 hours old from the two supplier colonies were chosen and taken to laboratory for grafting. 40 larvae were grafted in to 200 standard plastic queen cell cups lubricated (primed) with a drop of dilute fresh royal jelly of 1:1 (distilled water to royal jelly) ratio and 40 of them placed arranged on two 
wooden cell bars and fixed into a frame (Figure 2). After five nursery frames prepared in the same way, all framed cell bars were taken and placed in the five colonies made queenless one day in advance for acceptance and starting queen cells. 24 hours after placed in starter colonies for acceptance, inspection of the colonies was done and number of accepted larvae for each starter colonies recorded and similar activities performed for Jenter queen rearing system was adopted for grafting as well for the whole study period. The testing was conducted for 8 batches per colony for the whole study period. Data on number of accepted larvae, sealed queen cells and hatched queens converted to percentage based on the number of given larvae and were subjected to ANOVA and Student's test.

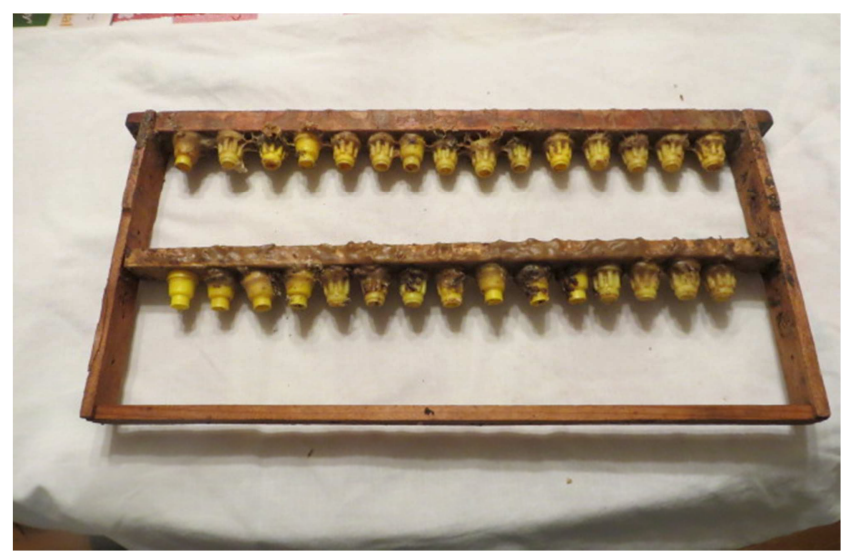

Figure 2. Arrangements of queen cell cups arranged on wooden bars in a frame.

\section{Results and Discussion}

\subsection{Effects of Treatments on Larval Acceptance}

The result of the study revealed that there was significant difference $(p<0.001)$ between the two techniques in the larval acceptance rate (Table 1). In Karl Jenter queen rearing system, the average acceptance was $78.19 \%$ while in Doolittle grafting method the rate was only $50.81 \%$. Similarly, differences in mean acceptance of queen cell cups in Cupkit apparatus, Karl Jenter apparatus, plastic cell cups and wax cell cups with acceptance values of 66.00, 50.00, 58.66 and $56.00 \%$, respectively were reported by Dhaliwal et al. (2017) [15]. However, the acceptance rate for Jenter queen rearing system in this study $(78.19 \%)$ is higher than the acceptance rate in Karl Jenter apparatus reported by [15] which was $50 \%$.

The observed significantly higher acceptance rate for Karl Jenter over Doolittle grafting system in this study could be due to various factors. But the most important factor could be due to lack of identifying appropriate age and injury to the grafted larvae in Doolittle grafting due to personal error compared to Karl Jenter system. In line with this, [15] indicated that graftless method has better acceptance as it avoids any injury to larva and larva is fed royal jelly from first day onwards. Similarly, Büchler et al. (2013) described that acceptance of larvae depends on different factors, among which the most important include: quality, strength and developmental stage of the nurse colonies, age of the workers, age of the grafted larvae, presence of open brood in the cell-starting colonies, rearing sequence and method of rearing [6]. Several investigators $[2,9,16]$ also indicated that the responses of colonies towards different queen rearing techniques are greatly affected by agro ecological conditions, race of honeybees and pollen source plants. On top of these, low acceptance level in Doolittle grafting compared to Karl Jenter in this study could also be due to failure to work rapidly while grafting the larvae from the worker comb to the queen cells and maintaining suitable environmental conditions.

Table 1. Comparative responses of Apis mellifera bandasii colonies to Jenter and Grafting queen rearing techniques to acceptance of larvae and sealed queen cells on the bases of given 40 larvae per colony. Values are mean \pm standard deviations (SD) ( $n=1600)$ larvae per rearing technique. Values followed with different letter in a column shows significant difference between seasons for each technique $(P<0.05)$.

\begin{tabular}{|c|c|c|c|c|}
\hline \multirow{2}{*}{ Rearing technique } & \multirow{2}{*}{ Rearing Seasons } & \multirow{2}{*}{ Accepted larvae (\%) } & \multicolumn{2}{|c|}{ Sealed queen cells $(\%)$ on the bases of: } \\
\hline & & & Given larvae & Accepted larvae \\
\hline \multirow{3}{*}{ Jenter method } & Sept - Oct & $84.13 \pm 4.39^{\mathrm{a}}$ & $50.13 \pm 5.53^{\mathrm{a}}$ & $56.11 \pm 10.08^{\mathrm{a}}$ \\
\hline & April - May & $72.25 \pm 5.86^{\mathrm{b}}$ & $35.37 \pm 7.00^{\mathrm{b}}$ & $52.37 \pm 9.35^{\mathrm{a}}$ \\
\hline & Overall & $78.19 \pm 7.94$ & $42.75 \pm 9.82$ & $54.24 \pm 9.78$ \\
\hline \multirow{3}{*}{ Grafting method } & Sept - Oct & $58.00 \pm 7.05^{\mathrm{a}}$ & $28.50 \pm 5.98^{\mathrm{a}}$ & $55.52 \pm 10.21^{\mathrm{a}}$ \\
\hline & April - May & $43.62 \pm 5.76^{\mathrm{b}}$ & $22.63 \pm 3.58^{\mathrm{b}}$ & $52.33 \pm 8.70 \mathrm{a}$ \\
\hline & Overall & $50.81 \pm 9.66$ & $25.56 \pm 5.70$ & $53.93 \pm 9.47$ \\
\hline L.S.D $(\mathrm{P}=0.05)$ & & 27.31 & 17.06 & N.S. \\
\hline
\end{tabular}

\subsection{Effects of Treatments on Sealing of Queen Cells (Pupae)}

The variation of queen cells sealing was significantly different $(P<0.0001)$ between the two methods on the bases of given larvae. Analysis of the data (Table 1) indicated that sealing of cell cups from Karl Jenter was $42.75 \pm 9.82 \%$ while it was only $25.56 \pm 5.70 \%$ from grafted cell cups in Doolittle grafting out of the total 1600 larvae provided for each system. However, there was no significant differences between the two techniques with regards to sealing of the queen cell cups on the basis of accepted larvae (compare $54.24 \pm 9.78 \%$ and $53.93 \pm 9.47 \%$ for Karl Jenter and Doolittle grafting, respectively). The similarity in sealing level of queen cell cups from Karl Jenter and Doolittle grafting on the basis of accepted larvae can be explained by several factors of which the amount of royal jelly produced by nurse bees to feed the larvae, number of available worker bees for nursing, 
nutritional quality of pollen and race of the bees may contribute and these required to be investigated.

In this study, sealing rate of the queen cells both on the bases of given and accepted larvae was generally lower compared to previous reports. For example, Dhaliwal et al. (2017) reported that sealing of cell cups ranged from 50.67\% to $60.67 \%$ on the basis of total cell cups given while it was ranged from 88.57 to $97.50 \%$ on the basis of cell cups accepted for different queen rearing techniques [15]. Similarly, N. Adgaba et al. (2018) reported that $71.84 \%$ of sealed larvae (from the total grafts) into pupae stage in wet grating for A. mellifera jemenitica in Saudi Arabia [7]. Generally, in different queen rearing techniques the rate of sealing queen cells reported to be varied. But besides the types of techniques used, the population size of the colonies, amount food resources available for the bees during the breeding seasons, races of the bees were indicated as some of the factors to influence different parameters in queen rearing [15-17]. Therefore, the relatively low rate of sealed queen cells for both queen rearing techniques in this study could be one of or the combination of these factors and this suggests the importance of further investigations to determine the important factors that affect raising and sealing of queen cells in different queen rearing techniques under local conditions for different honeybee races.

\subsection{Effects of Treatments on Hatching of Virgin Honeybee Queens}

The rate of hatching (out of the total given larvae) into virgin queen stage in Karl Jenter and Doolittle grafting systems were about 23 and $23.8 \%$, indicating no significant difference between the two techniques (Table 2). However, the variations in queen emergence rates based on accepted larvae and sealed queen cells were found to be very significant $(\mathrm{P}<0.001)$. Accordingly, the emergence of queen bees on the basis of accepted larvae and sealed queen cells were 29.22 and $55.71 \%$, respectively for Karl Jenter while the corresponding rate of emergence for Doolittle grafting were 46.47 and $86.68 \%$, respectively indicating significant difference between the two methods. The result of this study agrees with the findings of Dhaliwal et al. (2017) who reported that the rate of emerged queens on the basis of accepted cells for different rearing techniques were significantly different [15]. According to the report by Dhaliwal et al. (2017), the emergence of queen bees in the Cupkit apparatus and plastic cell cups were 83.28 and $83.34 \%$, respectively, while the respective rates for Karl Jenter apparatus and wax cell cups were 52.20 and $54.73 \%$ in that order [15]. In another report by Cengiz, Emsen, and Dodologlu (2009), 100.00\% rate of queen bee emergence were recorded in queenright and queenless colonies for the grafted larvae raised with Doolittle method [18]. Similarly, ÖNK et al. (2016) reported $100.00 \%$ queen bee emergence rate of accepted larvae for Caucasian race of A. mellifera honeybees [19]. In this study, sealing of queen cells and emergence rate of queen bees on the basis of accepted larvae was significantly $(\mathrm{P}<0.001)$ higher for Doolittle grafting compared to Karl Jenter system. However, the larval acceptance rate was significantly $(\mathrm{p}<0.001)$ higher for Karl Jenter system compared to Doolittle grafting method (Table 1). On the other hand, the queen emergence rate for the two techniques based on the basis of given larvae was similar, indicating that accepted larvae less successfully sealed and converted into virgin queen stage in Karl Jenter than Doolittle grafting. On the base of the current result, both systems can be practiced for rearing queen bees as the number of queen bees obtained is similar. Though the bees responded to the two methods similarly, the percent emergence was low for both methods. This could be due to environmental factors such as: humidity and temperature which may negatively affect the rearing colony and/or the feed supply of the nurse colony. So, this should be the subject of future investigation to identify important factors that affect different queen rearing parameters, which result in low rate of queen emergence. If percent emergence of queen bees on the basis of given larvae improved, at least Karl Jenter system can be used to yield higher number of queens. If so, the method can be an excellent option for those who face difficulties in identifying appropriate larval age and lack skill in grafting can opt for commercial queen bee rearing. However, there might be a difference in quality of the queens obtained from these two methods. Therefore, further study should be conducted to evaluate the performance of queens reared using the two techniques.

Table 2. Mean $\pm S D$ of percent queen cells emerged (hatched) into virgin queens using based on given and accepted larvae and sealed queen cells under Jenter and grafting rearing techniques. Values followed by similar letters show no significant difference between seasons for each technique $(P<0.05)$.

\begin{tabular}{|c|c|c|c|c|}
\hline \multirow{2}{*}{ Rearing technique } & \multirow{2}{*}{$\begin{array}{l}\text { Queen rearing } \\
\text { Seasons }\end{array}$} & \multicolumn{3}{|c|}{ Emergence (\%) of queens on the bases of: } \\
\hline & & given larvae & accepted larvae & sealed queen cells \\
\hline \multirow{3}{*}{ Jenter method } & Sept and Oct & $25.25 \pm 4.28^{\mathrm{a}}$ & $30.21 \pm 4.30^{\mathrm{a}}$ & $56.36 \pm 12.41^{\mathrm{a}}$ \\
\hline & April and May & $20.50 \pm 3.20^{\mathrm{a}}$ & $28.23 \pm 4.44^{\mathrm{a}}$ & $55.07 \pm 15.57^{\mathrm{a}}$ \\
\hline & Overall & $23.08 \pm 4.44$ & $29.22 \pm 4.43$ & $55.71 \pm 13.90$ \\
\hline \multirow[b]{2}{*}{ Grafting method } & Sept and Oct & $22.88 \pm 4.36^{\mathrm{a}}$ & $46.78 \pm 10.66^{\mathrm{a}}$ & $90.83 \pm 14.50^{\mathrm{a}}$ \\
\hline & April and May & $22.75 \pm 2.84^{\mathrm{a}}$ & $46.16 \pm 1254^{\mathrm{a}}$ & $82.54 \pm 17.32^{\mathrm{a}}$ \\
\hline L.S.D $(\mathrm{P}=0.05)$ & & N.S. & 17.25 & 30.97 \\
\hline
\end{tabular}




\subsection{Effects of Seasons on Different Queen Rearing Parameters}

Tables 1 and 2 illustrates rates of different queen rearing parameters of $A$. mellifera bandasii colonies to Jenter and Grafting queen rearing techniques under two seasons. The difference between seasons in terms of larva acceptance and sealed queen cell rates were statistically significant $(\mathrm{P}<0.01)$. Larva acceptance and sealed queen cell rates were found to be higher in September and October than April and May. Similarly, Gene, Emsen and Dodologlu (2005) showed that rearing seasons were found to be significant in affecting acceptance of larvae [20]. This difference in performance level in different seasons may be arise from the fact that different floral resources may be preferred by honeybees to focus more breeding offspring in one season and to focus on honey storage another season. Another explanation for lower acceptance in April and May could also be lower swarming tendency of the bees during this season under local conditions. However, the other queen rearing parameters were not influenced by the seasons. This result is in line with a previous study report by Nuru and Dereje (1999) on the responses of local honeybees to different queen rearing method [16].

\section{Conclusion}

In beekeeping, a honeybee queen has significant effect on several production and productivity traits such as disease resistance, prolificacy, and early population build up, surplus honey storing tendency and many other behavioral characters. Artificial queen rearing techniques are among the important approaches to help producing of queens with desirable characters in beekeeping. In this article, we present and discuss two queen-rearing methods, Karl Jenter and Doolittle grafting, which are based on scientific technique yet pragmatic and easy to implement. The study result found that both Karl Jenter and Doolittle grafting queen rearing technique are similar in percentage of hatched queen bees. The result of the study also support the thesis that seasons of queen rearing have significant effect on larvae acceptance and queen emergence. According to the results obtained in this study, we can conclude that it is possible to rear queen bees for different purposes using both methods by considering the best season for rearing. However, we recommend Karl Jenter queen-rearing method as an excellent technique for those who face technical difficulties while carrying grafting and lack skill in identifying the appropriate larval age for grafting. We also recommend further studies to determine the important factors that affect the final success in obtaining hatched queens and their quality in these two queen-rearing techniques under local conditions.

\section{Acknowledgements}

The research financing, logistic facilitation and research site allocation were by Oromia Agricultural Research Institute, Holeta Bee Research Center. Publication of this article is supported by the Horizon 2020 Project SAMS 'Smart Apiculture Management Services', the project which receives funding from the Horizon 2020 European Union Research and Innovation Framework under Grant Agreement $\mathrm{N}^{\circ} 780755$.

\section{References}

[1] G. Ahmet and A. Hasan, "Reproductive Characteristics Of Turkish Honeybee (Apis Mellifera L.) Genotypes," J. Anim. Vet. Adv., vol. 4, no. 10, pp. 864-870, 2005.

[2] R. A. Morse, Rearing Queen Honey Bees: Second Edition 2nd ed. Edition. Retrieved from https://www.amazon.com/Rearing Queen Honey Bees- Roger A Morse/dp/ 1878075055. 1993.

[3] E. Crane, Bees and beekeeping: science, practice and world resources. 1990.

[4] H. H. Laidlaw and R. E. Page, Queen rearing and bee breeding. https://www.amazon.com/Queen-Rearing-BreedingHarry-Laidlaw/dp/187807508X. 1997.

[5] D. M. R. Serrano, "Queen rearing, Apeldoorn, The Netherlands.," O Apic., vol. 5, no. 16, pp. 39-41, 1997.

[6] R. Büchler et al., "Standard methods for rearing and selection of Apis mellifera queens," J. Apic. Res., vol. 52, no. 1, pp. 130, 2013.

[7] N. Adgaba et al., "The responses of Apis mellifera jemenitica to different artificial queen rearing techniques," Saudi J. Biol. Sci., pp. 4-9, 2018.

[8] S. B. Ahmad and S. A. Dar, "Mass rearing of queen bees, apis mellifera 1. (hym : apidae ) for bee colony development raised under the temperate conditions of kashmir," vol. 8, no. 3, pp. 945-948, 2013.

[9] K. Crailsheim et al., "Standard methods for artificial rearing of Apis mellifera larvae Standard methods for artificial rearing of Apis mellifera larvae," vol. 52, no. 1, pp. 1-15, 2013.

[10] S. W. Cobey, "Comparison studies of instrumentally inseminated and naturally mated honey bee queens and factors affecting their performance," vol. 38, pp. 14524-14531, 2013.

[11] E. BUESCU (LIPAN), M. R. GURĂU, and A. I. BÎRȚOIU, "Artificial Insemination on Apis Mellifera - Aspects of Artificial Inseminated Queen Performances and Factors That May Affect Their Performance," pp. 21-24, 2015.

[12] A. Nuru and W. Dereje, "Response of Ethiopian honeybees to different queen rearing techniques," in Proceedings of 7 th Annual Conference of Ethiopian Society of Animal Production, 26-27 May 1999, pp. 125-133., 1999, pp. 125-133.

[13] A. Zewudu, L. Gemechis, and A. Tadele, "The response of central highland honeybee, Apis mellifera bandasii to grafting and natural cell cup of queen rearing techniques," in Proceedings of the 20th Annual Conference of the Ethiopian Society of Animal Production (ESAP) held in Addis Ababa, Ethiopia, October 03 to 05, 2013.

[14] B. Amssalu, A. Nuru, S. E. Radloff, and H. R. Hepburn, "Multivariate morphometric analysis of honeybees (Apis mellifera) in the Ethiopian region," Apidologie, vol. 35, pp. 71-81, 2004. 
[15] N. K. Dhaliwal, J. Singh, and P. K. Chhuneja, "Comparative evaluation of Doolittle, Cupkit and Karl Jenter techniques for rearing Apis mellifera Linnaeus queen bees during breeding season,” J. Appl. Nat. Sci., vol. 9, no. 3, pp. 1658-1661, 2017.

[16] A. Nuru and W. Dereje, "Response of Ethiopian honeybees to different queen rearing techniques, Holeta Bee Research Center, P. O. Box 22, Holeta," 1999.

[17] A. Dodologlu, B. Emsen, and F. Gene, "Comparison of some characteristics of queen honey bees (Apis mellifera 1.) reared by using doolittle method and natural queen cells," J. Appl. Anim. Res., vol. 26, pp. 113-115, 2004.
[18] M. Cengiz, B. Emsen, and A. Dodologlu, "Some characteristics of queenbees (Apis mellifera L.) rearing in queenright and queenless colonies," J. Anim. Vet. Adv., vol. 8, no. 6, pp. 1083-1085, 2009.

[19] K. ÖNK, M. M. CENGIZ, K. YAZICI, and T. KIRMIZIBAYRAK, "Effects of Rearing Periods on Some Reproductive Characteristics of Caucasian (Apis mellifera caucasica) Queen Bees," Atatürk Üniversitesi Vet. Bilim. Derg., vol. 11, no. 3, pp. 259-259, 2016.

[20] F. Gene, B. Emsen, and A. Dodologlu, "Effects of rearing period and grafting method on the queen bee rearing," J. Appl. Anim. Res., vol. 27, no. 1, pp. 45-48, 2005. 